\title{
Comprehensive care: meanings for teachers and nursing students
}

\author{
Cuidado integral: significados para docentes e discentes de enfermagem
}

Rosiane Filipin Rangel ${ }^{1}$, Dirce Stein Backes ${ }^{2}$, Silomar Ilha², Hedi Crecencia Heckler de Siqueira ${ }^{1}$, Fernanda Demutti Pimpão Martins ${ }^{3}$, Claudia Zamberlan²

Objective: to understand the meaning of comprehensive care in the view of teachers and nursing students. Methods: qualitative research conducted with seven teachers and six students of the nursing course of a higher education institution. Data were collected using the Focal Group technique and subjected to thematic content analysis. The comprehensive care construct was used for this article as based on authors who talk with ownership of the theme. Results: the students perceive the comprehensive care as the subjective interaction with others respecting human uniqueness through a gradual construction in order to meet the apparent and non-apparent needs. Conclusion: teachers and students reported that comprehensive care depends on a network of actions and needs to be instigated since academic education.

Descriptors: Comprehensive Health Care; Nursing Care; Nursing.

Objetivo: compreender o significado de cuidado integral para docentes e discentes de enfermagem. Métodos: pesquisa qualitativa, realizada com sete docentes e seis discentes do curso de enfermagem de uma instituição de ensino superior. Os dados foram coletados, por meio da técnica de Grupo Focal e submetidos à análise de conteúdo, na modalidade temática. Para esse artigo utilizou-se o construto cuidado integral, baseado em autores que discorrem com propriedade sobre a temática Resultados: os discentes percebem o cuidado integral como a interação subjetiva consigo e com o outro respeitando a singularidade humana por meio de uma construção gradual a fim de atender às necessidades aparentes e não aparentes. Conclusão: docentes e discentes referiram que o cuidado integral depende de uma rede de ações e precisa ser instigado desde a formação acadêmica.

Descritores: Assistência Integral à Saúde; Cuidados de Enfermagem; Enfermagem.

\footnotetext{
${ }^{1}$ Universidade Federal do Rio Grande. Rio Grande, RS, Brazil.

${ }^{2}$ Centro Universitário Franciscano. Santa Maria, RS, Brazil.

${ }^{3}$ Universidade Federal de Pernambuco. Recife, PE, Brazil.

Corresponding author: Rosiane Filipin Rangel

Escola de Enfermagem, Rua General Osório S/nº, CEP: 96.201-900. Rio Grande, RS, Brazil. E-mail: rosianerangel@yahoo.com.br
} 


\section{Introduction}

Nursing care has focused for a long time on disease-centered hospital practice, in the biomedical model. However, in view of the diversity present in the everyday practice of this area, it is considered that this model does not meet the needs of human beings in all their dimensions, namely, the physical, socio-cultural, psychological and spiritual dimensions. From this perspective, it is important to return to nursing care practices, to the dimensions of the human being ${ }^{(1)}$.

Thus, there is a need to revisit the issue of care because the multiple dimensions of the human being, since Florence Nightingale, the pioneer of modern nursing, are at the heart of health practices ${ }^{(2-3)}$. However, with the evolution of the technological process focused on products, this care has become, in some contexts, punctual, linear and fragmented, where the human being is considered a dissociated part of a whole.

As a result of this understanding of human beings, in dissociated parts, knowledge has been grouped into subjects and, therefore, professional practices have followed the same path ${ }^{(4)}$. Thus, the trend was to perceive and consequently treat/care in an isolated, fragmented and sometimes decontextualized form. This setting becomes evident in the significant number of hiper-specializations.

Even when care does not occur through hyper-specialization, it is difficult to perceive its comprehensiveness, since it refers to the multiple dimensions of the human being, which include the bio-psycho-social and spiritual care ${ }^{(5)}$. Clinical practice allows us to infer that the bio-psycho-social care, if not achieved, is at least recognized by professionals. Spiritual care, although already evidenced in the literature, is not a reality often identified in the practice of nursing professionals ${ }^{(6)}$ and, therefore, this care remains dissociated.

The understanding of this reality is necessary because the possibility of a re-signifying the practice of nursing to achieve comprehensive care depends on it ${ }^{(7)}$. Comprehensive care is understood as one that meets the multiple dimensions of the human being. Integral care has multiple elements that can serve as a basis to think, plan and execute daily teaching in Nursing ${ }^{(8)}$. It should be noted that, when it comes to comprehensive care, the technological support in the form of products should not be disregarded because of their use and importance in health care settings. Technological support is one of the ways used to take care; however, this must be associated with sensitivity, respect, to the willingness to know the real needs of patients in order to care while seeking to encompass the dimensions that constitute the entirety of their being.

In this context, discussions about comprehensive care must permeate the discourse and practice of nursing professionals for its effectiveness in different health action scenarios. For this to happen, it is necessary to approach the theme and experience since academic training, to give way to is singularization and consequent application ${ }^{(7)}$.

The university is considered the main space for learning. In this context, the role of teachers is of fundamental importance, since they are among the responsible for the necessary changes, as well as mediators of diverse knowledge ${ }^{(7)}$. This justifies the need to understand the perception of teachers about the meaning of comprehensive care. With respect to the students, it is essential to know their perception because they may become multipliers to achieve comprehensive care in their daily work.

Thus, the study has the following research question: How nursing teachers and students understand the meaning of comprehensive care? In order to answer this question, the study aimed to understand the meaning of comprehensive care in the view of nursing teachers and students.

\section{Methods}

Qualitative study developed in a higher education institution located in the central region of the state of Rio Grande do Sul. Participants were teachers 
and students of the undergraduate nursing course. The sample selection was made through two draws: eight teachers were elected at random by the number of institutional enrollment and seven students from 3rd to 8th semesters of the course, based in the call list. It is noteworthy that the number of participating teachers invited to participate is in line with the maximum number recommended by the data collection technique (seven participants) ${ }^{(9)}$.

As for the students, a maximum number was not reached because the number of semesters and because we wanted to maintain a regular numberof participants per semester (one per semester). ${ }^{(9)}$ Seven teachers and six students of the nursing course participated in the study, therefore, comprising the sample of this study, a total of 13 participants.

The inclusion criteria for teachers were: be a nurse, develop professional activities directly with students. In relation to students: they should be studying nursing, enrolled between 3rd and 8th semester and present at the time of the draw. Teachers and students were excluded if they were absent during data collection due to health reasons, vacations and academic exchanges.

After the draw was made personally and individually, a formal invitation was made to each of the selected participants and, after acceptance, meetings of focal groups were scheduled. The focal group technique has interactive and participatory nature, which makes it possible to obtain information hardly achieved by means of other approaches ${ }^{(9-10)}$. The composition of the groups was structured in teachers and students in order to ensure homogeneity among the participants and allow the deepening of reflections.

Three meetings were held for each group, totaling six sessions, each lasting about one hour and thirty minutes in the presence of a moderator and an observer. The number of focal group meetings was defined according to saturation of data, that is, the meetings were interrupted from the moment when researchers found no new elements or information and when data started to become repetitive ${ }^{(11)}$.
The role of the moderator was to coordinate the whole process involving the focal group: planning meetings; defining themes; development of scripts for the meetings and conducting the group as a whole. The role of the observer was to collaborate with the moderator by registering sessions (dynamic, speaches and records), aid in the control of time and in the activities of the meeting ${ }^{(9-10)}$.

Sessions took place in a meeting room of the institution. The place was chosen for having adequate ventilation, light and acuity. Upholstered chairs and circular configuration facilitated the face to face interaction of participants ${ }^{(9-10)}$. The following issues were established for both groups: First session - What does it mean comprehensiveness in your opinion? Second session - What is the meaning of comprehensive care? What is the role of training in the execution of comprehensive/holistic care? Third session - What is the meaning of comprehensive care?

At the end of the third session of each group, all were invited to individually build a concept of comprehensive care. In the sequence, they were presented and discussed among the groups of teachers and students, formulating this way, a collective concept of about comprehensive care for each group.

The meetings held in January 2011 were recorded in MP3 player and transcribed in full length after the end of each session to avoid loss of information that could be relevant to the analysis, such as facial expressions and body posture ${ }^{(9-10)}$. At the beginning of each new meeting, the transcribed data were given to participants who performed the reading with a view to validating data ${ }^{(10)}$.

Data were analyzed using thematic content analysis technique ${ }^{(12)}$. Initially we proceeded to the pre-analysis; there was the overview and then the exhaustive reading of transcribed recordings, and definition of registration units; the, coding took place by grouping the texts of each meeting in record units; Finally, results were treated and interpreted. Result nterpretations from reading gave base for creating themes. 
For the present article did not use a specific theoretical framework, but the construct comprehensive care based on authors who are specialists on the theme ${ }^{(7-8,13-14)}$. To maintain anonymity of participants, they were identified throughout the text by the name of constellations, followed by the letter "T" for teachers and the name of stars, followed by the letter "S" in the case of students.

The study complied with the formal requirements contained in the national and international regulatory standards for research involving human beings.

\section{Results}

In the group of professors, all were female and had a master's degree. The time since obtention of the diploma ranged from seven to 25 years and the time working in the institution ranged from four to 24 years. In the group of nursing students, all were female and aged from 16 to 25 years. The analysis of transcripts and records of the sessions of focal groups with students identified the theme: Subjective interaction with oneself, with others and with teachers and Integral care and their interrelations.

\section{Subjective interaction with oneself, withothers and with teachers}

In the first session, while addressing the theme comprehensiveness, the students made reference to comprehensive care, which is also seen as a subject-subject relationship. I think, in the first session, when we speak of comprehensiveness, we have already addressed the issue of comprehensive care; all the time we approached what is care, which is the comprehensive care. When we formulated as a subject-subject complex construction, care is subject-subject (Procion S).

Comprehensive care should be provided in the subject-subject relationship, transcending the apparent needs, those that are usually the reason that lead the person to look for the health service, as often, the human being seeks help due to a momentary need. It is then that the professional should try to establish the necessary links to provide comprehensive care. Often, the first care happens by necessity. You go to the person because of the need that she or he presents, and from there, you can act, transcend those needs that arise. Then you're going to be able to exercise the comprehensive care. The moment you get this difference, you transcend, I think that's it (Syrian S). I think you need to talk to the patient, be together to discuss ways and methods that can intervene in the contact, it is necessary to establish bond (Spica S).

Thinking about comprehensive care means seeing the human being as a unique being, and one that needs to have its subjectivity worked and its essence respected. This type of service is simple but great; it is a daily construction that takes place from moments, an exchange of care that to happen satisfactorily, knowledge on the other is required. We work a lot with subjectivity, which means to transcend what we are seeing, what are the needs of the individual. For me, comprehensive care has a lot to do with the subjectivity of each person (Hadar S). It is a construction, it does not happen in a first visit, in the first contact. This should be understood: that comprehensive care does not come from a moment alone, but it is a construction of times, in short, of knowledge, of knowing the other. It is so simple, very grand. I need to know your integrity to be able to provide such comprehensive care (Canopus S).

In the view of one of the students, comprehensive care can be compared to a father-child care relationship. It comprises the construction of a comprehensive relationship, with extensive involvement of both parties. This situation, according to the participant, has to happen in the interaction of comprehensive care. I think nothing is better, in my opinion, to translate comprehensive care than the father/child care, which is one relationship where a construction occurs. There is no way of interaction not happening, we have to adapt and have to think of all child development stages. So, it is the best way to translate the comprehensive care, that of father towards a son (Arcturus S).

The participants began to question some terms used in discussions, as well as the sense in which they that had been used for comprehensive care. I think, why put this interrelationship before. I think the care, instead of being a 
construction, is first an interrelationship. Care is not built from nothing, you know. It is a subject-subject interrelationship, where we do all this, and from that which is built (Syrian S).

Similarly, the group discussed how this comprehensive care could be offered not only in theory but also in practice. First, the group agreed that there must be a construction and deconstruction of the subject, the environment of knowledge, the exchange of knowledge, making it possible, then, constant changes. Construction and deconstruction of the subject, the environment, learning, exchanging knowledge, always allowing the change (Syrian S).

Another participant reflected on the issue of deconstructing by explaining that deconstruction can be understood as getting close to an individual, seizing his ideas and adding new knowledge to his being. Thus, it was suggested changing the word for reconstruction. It is the reconstruction that is building what it was before, building upon what was already a construction, one that you're enhancing. A reconstruction, you aggregate (Canopus S).

However, a student argued that, for him, it is essential to deconstruct in order to build another concept. Thus, group members suggested the use of the three terms, in view of the importance of each in relation to comprehensive care: I think deconstruction is that, I think you have to say nothing of the other, but of yourself; so often you have to deconstruct yourself to be able to build. I would put the three, construction, deconstruction and reconstruction (Syrian S).

After joint discussions, the conclusion reached was that comprehensive care is a subjective interaction with oneself and with others, respecting human uniqueness, through a gradual construction in order to meet apparent and non-apparent needs.

\section{Comprehensive care and its interrelations}

Initially, teachers recognized that comprehensive care depends on a network of actions and needs to be instigated since the undergraduate training, because the human being is multidimensional. Today I can provide comprehensive care, but it is a matter of seconds the need of that same individual I cannot provide that service. So I depend on a network of care, and then there is the challenge and the critical node (Orion T). In pursuit of comprehensive care, I believe that one of the gaps that we could expand is to seek our peers who are accompanying the students in services, with this, a training network will exist, and assistance network will also broaden (Grus T).

In order that comprehensive care may occur in fact, involvement of at least three parts is essential: the teacher, the scholar and the person receiving care. Likewise, it is essential to deconstruct linear practices focused on technique. This change requires dialogue, awareness, complicity, and constitutes a major challenge because it works with cultures, values and transcends the educational process. It is involving, considering the triad, the teacher, the student and the being who will receive this care. From his conscience, his desire towards the other, for the one who learns and the one who teaches. So, the relation of service starts there. For this, I need to have dialogue with my colleagues of service, with all other professionals involved (Aquila T). I do not know if I have put myself in the role of both, listener and observer, a touch, a look much more than words, not in the sense of giving all the answers, but in order to build together. So, what ways do you believe we can think? (Columbus T).

In the perception of teachers, when integral care is the goal, including the community in this process is important. One of the ways in which they believe that this can be done is by granting autonomy and power for communities to think, create and develop strategies together with the health teams: I can have this knowledge, I can discuss very well with my team, I know everything. I'll do it, as I never thought about this matter. Such a simple thing, I will solve the problem of the world, but I do not teach to this people, I do not insert the people in this discussion, it does not work! (Sculptor T). It includes basic human needs inserted in the environmental context of this individual and the family, social, professional, and religious aspect. It is the whole and the single (Sagitta T).

The process towards comprehensive care requires sensitivity of professionals, and an awakening, disorganized change of thought; it requires that exceed the issue of welfare be transcended. Also, it is essential to know how to act in different situations and contexts, understanding the value that each human being attributed to their experiences: A family that the stu- 
dents and I were taking care took the children out from the room and gave the room to a pig. [The participant asked] But is it not easier to buy meat than raising this pig? No, my daughter, we like to get involved with the pet. The pork was allowed pet, and I wanted her to kill the pig. It was automatic, I let it out. So, this issue of value (Aquila T). I went to work in a health unit in my first month after I graduated. I got there and I noticed that the team working there, all, including workers, the cleaning staff, [all] were very demotivated, very sad. And I started doing a motivating work with them, so I did presentations, made comments every week; then I started doing it monthly. As they liked, and as I watched a difference in the assistance they were providing to patients who came to the unit (Draco T).

Participants understand that for the comprehensive care to happen, it is important to leave common sense and motivate staff who works directly in the process. Finally, teachers expressed the collective concept of comprehensive care: it is one that is linked to networks and runs through the educational process.

\section{Discussion}

In ordero develop care for human beings, aiming to encompass its dimensions, it is necessary to understand that this care is unique, autonomous and multidimensional. Moreover, the relationships and interactions need to occur through dialogue, flexibility, horizontality, creativity and dynamism among humans $^{(13)}$.

Comprehensive care was mentioned as a synonym of complete care, requiring a network of health care able to perceive not only the visible, but to go beyond this understanding, allowing contemplate the multiple dimensions of the human being. Thus, it is necessary to think about the elements that characterize and give meaning to care of others, from what is laid by public policies that, in turn, need to be taught to future nurses ${ }^{(8)}$. Caring through comprehensiveness requires dialogue and understanding of the human being as a whole, embedded in a social, political and economic contexts ${ }^{(15)}$.

Comprehensive care was perceived by tea- chers as a subjective interaction with oneself and with others, respecting human uniqueness through a gradual construction. This action needs to be complemented with other elements, which will give a more humanizing meaning to care, which cannot be seen just as a technical assistance and action ${ }^{(13)}$. Teachers and students that participated in the study recognize that comprehensive care must be instigated since academic education. For comprehensive care to be internalized by students, it is necessary that in the teaching process, teachers address this way of thinking and understanding the other, transcending the curriculum, viewing the human being as a whole and not in a fragmented way.

Therefore, teaching practice needs to be grounded in comprehensiveness, in health care, since the university can be understood as a space for collective, dynamic and creative learning that stimulates the process of action-reflection-action of participants within the context: educators, professionals, students and users of health services ${ }^{(15)}$. In this sense, the teacher has a key role to stimulate and sensitize students to make them feel important and valued on their care practice in the context in which they are inserted ${ }^{(16)}$.

Building comprehensiveness both in teaching and in practice requires changes, including the guarantee of dialogue to establish partnership relations between the subjects involved in the process - education, services and community ${ }^{(14)}$. In this regard, when the aim is comprehensive care, it is important to include the community in this process. For this, it is essential to grant autonomy and power for communities to think, create and develop strategies together with the health teams.

Approaching care through comprehensiveness in the nursing training process is necessary for training professional and personal identity ${ }^{(15)}$. Thus, the process of knowledge construction, based on comprehensive care, has a greatest potential to be reached and to be made effective in practice ${ }^{(14)}$. Teachers need to reflect on their teaching performance, driving it in order to sensitize the student, so that this may think 
care as a human value and a nursing work focus ${ }^{(8)}$.

In this research, it was seen that teachers have this view, as argued the teaching-learning process as a possibility to achieve comprehensive care. However, it is necessary to instigate the (future) professionals to develop their sensitivity. They consider the need of a shift in the way of thinking, going beyond the conservative approach, understanding the value that each human being attributed to their experiences. This thinking is in line with what is discussed in another study that showed that the student-teacher interaction should be formed based on human values and focused on the specific needs, namely, on the uniqueness of each human being. The development of both teachers and students, and thus the improvement of care, is a result of this interaction ${ }^{(17)}$.

With this understanding, some nursing schools have revised their curriculum considering the need to use new methods to enter the students in the communities in an active and participatory way ${ }^{(15,18)}$. The axis of comprehensiveness showed significant changes in the construction of knowledge from integrative teaching approaches. It has also shown that nursing courses have sought training based on the real needs of the population who are under their care by taking students closer in service ${ }^{(18)}$.

Nursing students who participated in this research recognized the importance of experiencing integral care in their health practices, going beyond the walls of the university, a place that is sometimes the only space where this theme is discussed. Thus, the importance of investing every day more in innovative teaching and learning approaches, in entrepreneurs and drivers of social involvement with a view to reach the comprehensive care becomes evident. Through this approach, it is believed that the hosting, resoluteness and bond formation are facilitated, going beyond compliance with the biological needs, by understanding the needs of the community expressed in the relational process that approximates caregivers and patients $^{(8)}$.
This relational process leads to the care and also teaching, which, when properly conducted, enable to reach sensitivity in students for their nursing training in comprehensive health $\operatorname{care}^{(8)}$.

\section{Conclusion}

Understanding the meaning of comprehensive care is linked to the completeness, something that takes place in the meeting between subjects, where the approach allows to identify the needs that require immediate assistance and others that need to be explored to be better understood. Teachers and students reported that comprehensive care depends on a network of actions involving various actors (nurses, teachers, students and patients) and needs to be instigated, especially during academic training.

\section{Collaborations}

Rangel RF and Backes DS contributed to the project design, collection, analysis and interpretation of data, and writing the article. Ilha S, Siqueira $\mathrm{HCH}$, Martins FDP e Zamberlan C contributed to the relevant critical writing and analysis of the content and final approval of the version to be published.

\section{References}

1. Serrano MTP, Costa ASMC, Costa NMVN. Cuidar em enfermagem: como desenvolver $\mathrm{a}(\mathrm{s})$ competência(s). Referência. 2011; 3(3):15-23.

2. Moreschi C, Siqueira DF, Dalcin CB, Grasel JT, Backes DS. Homenagem a Florence Nightindale e compromisso com a sustentabilidade ambiental. Rev Baiana Enferm. 2011; 25(2):203-8.

3. Haddad VCN, Santos TCF. A teoria ambientalista de Florence Nightingale no ensino da escola de enfermagem Anna Nery (1962 - 1968). Esc Anna Nery. 2011; 15(4):755-61.

4. Morin EA. Cabeça bem-feita: repensar a reforma, reformar o pensamento. Rio de Janeiro: Bertrand Brasil; 2010. 
5. Fracolli LA, Zoboli ELP, Granja GF, Ermel RC. The concept and practice of comprehensiveness in Primary Health Care: nurses' perception. Rev Esc Enferm. USP. 2011; 45(5):1135-41.

6. Caldeira S, Branco Zita C, Vieira M. A espiritualidade nos cuidados de enfermagem: revisão da divulgação científica em Portugal. Rev Enf Ref. 2011; 3(5):145-52.

7. Rangel RF, Backes DS, Pimpão FD, Costenaro RGS, Martins ESR, Diefenbach GDF. Concepções de Docentes de Enfermagem Sobre Integralidade. Rev Rene. 2012; 13(3):514-21.

8. Castro M,PereiraWR.Cuidado integral: concepções e práticas de docentes de enfermagem. Rev Bras Enferm. 2011; 64(3):486-93.

9. DebusM.Manualparaexcelênciaemlainvestigacion mediante grupos focales. Washington: Academy for Educational Development; 1997.

10. Barbour R. Grupos focais. Porto Alegre: Artmed; 2009.

11. Pires AP. Amostragem e pesquisa qualitativa: ensaio teórico e metodológico. In: Poupart J, Deslauriers JP, Groulx LH, Lapemère A, Mayer R, Pires AP, organizadores. A pesquisa qualitativa: enfoques epistemológicos e metodológicos. Petrópolis: Editora Vozes; 2008. p. 154-211.

12. Minayo MCS. O desafio do conhecimento: pesquisa qualitativa em saúde. São Paulo: Hucitec; 2013.
13. Moreschi C, Siqueira DF, Piexak DR, Freitas PH, Rangel RF, Morisso TS, et al. Interação profissionalusuário: apreensão do ser humano como um ser singular e multidimensional. Rev Enferm UFSM. 2011; 1(1):22-30.

14. Santana FR, Nakatani YK, Freitas AMM, Souza ACS, Bachion MM. Integralidade do cuidado: concepções e práticas de docentes de graduação em enfermagem do Estado de Goiás. Ciênc Saúde Coletiva. 2010; 15(suppl.1):1653-64.

15. Lima MM, Reibnitz KS, Prado ML, Kloh D. Comprehensiveness as a pedagogical principle in nursing education. Texto Contexto Enferm. 2013; 22(1):106-13.

16. Ahn YH, Choi J. Factors affecting Korean nursing student empowerment in clinical practice. Nurse Educ Today. 2015; 35(12):1301-6.

17. Salehian M, Heydari A, Aghebati N, Karimi Moonaghi H, Mazloom SR. Principle-based concept analysis: Caring in nursing education. Electron Physician [Internet]. 2016 [cited 2016 Sept 13]; 8(3):2160-7. Available from: http://www.ncbi. nlm.nih.gov/pmc/articles/PMC4844483/

18. Kloh D, Reibnitz KS, Boehs AE, Wosny AM, Lima MM. The principle of integrality of care in the political-pedagogical projects of nursing programs. Rev Latino-Am Enfermagem. 2014; 22(4):693-700. 